\title{
Relationship between the development of Simulium maculatum (Diptera: Simuliidae) and the thermal regime
}

\author{
RASA BERNOTIENĖ and GALINA BARTKEVIČIENĖ \\ Nature Research Centre, Akademijos 2, LT-08412 Vilnius-21, Lithuania; e-mails: rasab@ekoi.lt; galina@ekoi.lt
}

Key words. Simuliidae, Simulium maculatum, development, temperature, precipitation, atmospheric circulation

\begin{abstract}
Warmer temperatures in the past 30 years have significantly influenced the seasonal development of insects throughout Europe. As a result of the outbreaks of black flies that have occurred in southeastern Lithuania since the 1970s it is hypothesized that this increase in black fly activity is due to the change in climate. To test this hypothesis the development of Simulium maculatum Meigen under different conditions was determined. This revealed that the time of hatching of $S$. maculatum eggs in Lithuania was influenced by winter air temperatures, especially those in March. Pupation in S. maculatum is associated with the increase in air and water temperatures that occur at the end of April and in May. The emergence of $S$. maculatum black flies occurs most often in May. At a water temperature of $13.2^{\circ} \mathrm{C}$ (1999), S. maculatum took 42 days to develop and half this time (21 days) when the water temperature was $18.8^{\circ} \mathrm{C}(2005)$. The number of black flies that emerged each year was determined by air temperature but unaffected by rainfall in June (either per month or per ten-day period).
\end{abstract}

\section{INTRODUCTION}

The black fly Simulium (Byssodon) maculatum Meigen was described from Germany in 1804 . Once widespread $S$. maculatum is now extinct in many of the large river systems in central Europe (Zwick \& Crosskey, 1980). Due to its rarity in central Europe little is known about its biology.

S. maculatum has been an abundant inhabitant of the Nemunas River in Lithuania since the 1970s. It is the main pest species in southern Lithuania (Žygutiene \& Pakalniškis, 1997; Žygutienè \& Sprangauskaitè, 1998) and the subject of biological control since 1998 (Pakalniškis et al., 2006). Larvae of $S$. maculatum develop over the period April to June and imagines emerge from May to July. The time of eclosion and development of the larvae in the Nemunas River varies between years. Hence, the schedule of black fly control measures in the Nemunas River, which depend on larval eclosion and development, also varies between years.

The duration of the development from egg to adult in Simuliidae depends on species and water temperature. An increase in temperature usually accelerates embryonic development (Crosskey, 1990). Therefore, temperature is an important factor affecting larval eclosion and development, and the time of emergence of the bloodsucking females.

Global warming is increasingly affecting ecosystems (Lemoine et al., 2007) and therefore it is important to understand the response of different animal species, in this case blood-sucking black flies, to regional changes in thermal regimes.

The aim of this study was to determine the relationship between the development of Simulium maculatum black flies and the local thermal regime and the conditions of atmospheric circulation, thermal and precipitation regime that result in outbreaks of female black flies.

\section{MATERIAL AND METHODS}

Larvae and pupae of black flies were collected in the Nemunas River (in Druskininkai, 54 $1^{\prime} 10 \mathrm{~N}, 23^{\circ} 58^{\prime} 20 \mathrm{E}$ ) from 1997 to 2009 . The abundance of black fly larvae and pupae on aquatic vegetation was estimated. Uniform band-shaped leaves of Glyceria maxima (Hartm.) were collected from the stream and the abundance of Simulium maculatum larvae and pupae per $1 \mathrm{dm}^{2}$ of the leaf surface was determined. Three samples were collected every 5-7 days from the beginning of April until the beginning of July. As $S$. maculatum larvae are morphologically very distinctive, larvae in the second to the final instar are easily identified (Rubtsov, 1956).

Larval eclosion and duration of development (the period between hatching and pupation) were determined. Adult bloodsucking black flies were collected from several people using a pooter (at least three samples were collected from a locality per day) within a $10-\mathrm{min}$ period after $5 \mathrm{~min}$ of waiting. The time of year when the greatest number of bloodsucking black flies attacked a person per 10-min period was recorded for each year.

Dates of larval eclosion of Simulium maculatum were recalculated in terms of the number of days since January 1. Upper and Lower Quartiles were computed for each parameter investigated. If the appearance of black fly larvae and pupae in a particular year exceeded the Upper Quartile limit, their appearance was considered to be late; if below the Lower Quartile limit, their appearance in that year was considered to be early. The analysis of the duration of development of the black fly was carried out in an analogous way: If the duration of the insect development exceeded the Upper Quartile limit, it was considered to be long; if below the Lower Quartile limit, the development duration was regarded as short. The high ( $>$ Upper Quartile) and low ( $<$ Lower Quartile) numbers of attacking adults were established in a similar way.

Values of the monthly and ten-day period (I, II, III) air temperatures $\left({ }^{\circ} \mathrm{C}\right)$ and precipitation $(\mathrm{mm})$ were obtained from the Varena Meteorological Station (MS) and the temperature of the water in the Nemunas River $\left({ }^{\circ} \mathrm{C}\right)$ at Druskininkai for the period 1997-2009 were obtained from the Lithuanian Hydrometeorological Service. Data from the Varena MS were chosen for 


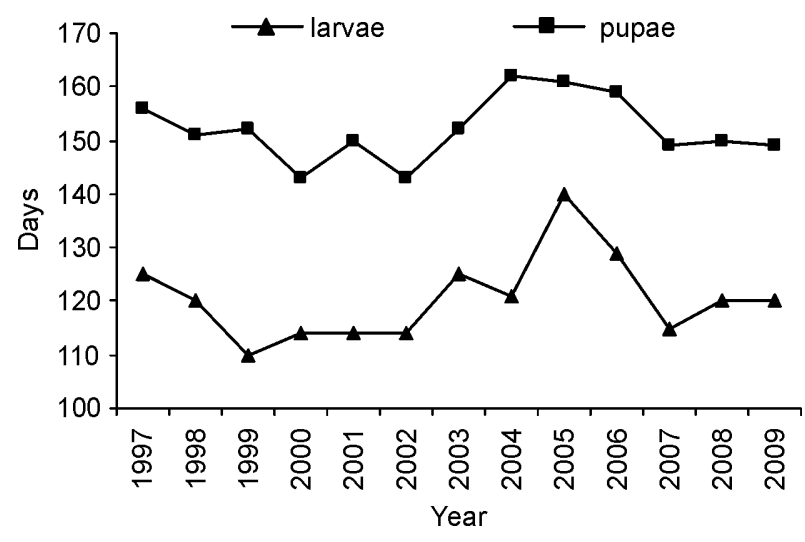

Fig. 1. The time of larval emergence and pupa formation (the number of days since January 1 until the first day of hatching and pupae formation) of $S$. maculatum each year from 1997 to 2009.

analysis because this station is the nearest $(58 \mathrm{~km})$ to the black fly observation site. Anomalies in the temperature and precipitation at particular times were based on departures from the longterm (1971-2000) mean.

If the temperature $\left(\mathrm{t},{ }^{\circ} \mathrm{C}\right)$ in a particular month or the ten-day period under analysis was lower than $\left(\mathrm{t}_{\text {mean }}-\sigma\right)$, it was considered to be low. And, vice versa, if the temperature was higher than $\left(\mathrm{t}_{\text {mean }}+\sigma\right)$, it was considered to be high $\left(\mathrm{t}_{\text {mean }}-\right.$ long-term mean, $\sigma$-standard deviation)

The study covered the winter period from January through to March. This period was chosen because winter-type circulation in the eastern Baltic region becomes dominant only in late December and persists for two or three months (Bukantis, 1994).

In June, when populations of adult black flies peak, conditions of atmospheric circulation were analyzed. Composite maps of sea level pressure (SLP) were drawn for the European region $\left(30-80^{\circ} \mathrm{N}, 20^{\circ} \mathrm{W}-45^{\circ} \mathrm{E}\right)$ for June and for separate ten-day periods in June.

To test the relationship between the aforementioned parameters a multiple regression analysis was carried out. The determination coefficient $\left(\mathrm{R}^{2}\right)$, F-test $(\mathrm{F})$ and $p$ were calculated. All statistical calculations were made using the STATISTICA 6 package for Microsoft Windows 2000.

\section{RESULTS}

\section{Preimaginal stages}

Simulium maculatum eggs hatched in the river Nemunas between April 20 and May 20. The greatest difference in hatching dates of $S$. maculatum in different years was 30 days (Fig. 1).

The beginning of the larval development in spring was determined by the mean winter temperature (JAN-MAR) $\left(\mathrm{y}=-2.4224 \mathrm{x}+116.64, \mathrm{R}^{2}=0.38, p<0.05, \mathrm{~F}=6.74\right)$ (Fig. 2 ) and especially the temperature in March (Fig. 3) $\left(\mathrm{y}=-2.5818 \mathrm{x}+122.33, \mathrm{R}^{2}=0.58, p<0.05, \mathrm{~F}=14.91\right)$.

In 1997-2002 and in 2007-2009 the mean winter air temperature exceeded the long term average and the beginning of $S$. maculatum development was close to the mean of 121 days from 1st January or earlier. Negative temperature deviations in winter recorded over a period of several years (2003-2006) were associated with a later appearance of black fly larvae (Figs 1,2). Important for

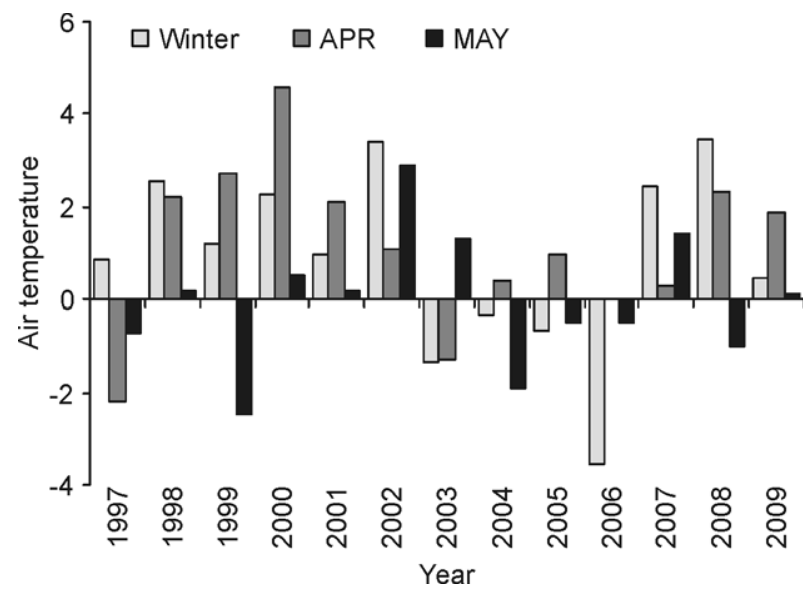

Fig. 2. Departures of the winter (January-March), April and May air temperature from the norm $\left(\Delta \mathrm{t},{ }^{\circ} \mathrm{C}\right)$ over the period 1997 to 2009.

the beginning of $S$. maculatum development is the air temperature in the third ten-day period of April when most of the eggs of this species hatch $(\mathrm{y}=-1.7761 \mathrm{x}+$ $\left.138.1356, \mathrm{R}^{2}=0.44, p<0.05, \mathrm{~F}=8.53\right)$.

The analysis of the beginning of black fly development using the Upper and Lower Quartiles revealed that the emergence of the first larvae was extremely late in 2005 and 2006 and early in 1999 .

In 2005 the winter and spring thermal regimes were normal (Fig. 2). However, in the third ten-day period of April air temperature fell as low as $4.8^{\circ} \mathrm{C}$ and was the lowest temperature recorded in the third ten-day period of April throughout this study. It was only in the second ten-day period of May that air temperature rose to $9.5^{\circ} \mathrm{C}$. In this year the latest date on which $S$. maculatum eggs hatched (the $20^{\text {th }}$ of May) was recorded.

In 2006, the average JAN-MAR air temperature was low $\left(\Delta \mathrm{t}=-3.5^{\circ} \mathrm{C}\right.$, Fig. 2) and spring was late, with the typical winter temperature regime persisting in the rivers of Lithuania into March. During this time rivers were covered with ice up to $50 \mathrm{~cm}$ thick (www.meteo.lt). The mean air temperature in March was lower than the longterm mean by $3.6^{\circ} \mathrm{C}$. Egg hatch in this year started in the first ten-day period of May, later than in most years.

In contrast, in 1999 air temperature was higher than the long-term mean temperature by $2.7^{\circ} \mathrm{C}$ and development of $S$. maculatum started early (April 20). In 2000 larvae of $S$. maculatum were recorded early (April 23). That year was distinguished by exceptionally high air temperatures in April (Fig. 2).

The time of pupation depended on air temperatures in the third ten-day period of April $(\mathrm{y}=-1.4152 \mathrm{x}+166.1$, $\left.\mathrm{R}^{2}=0.49, p<0.01, \mathrm{~F}=10.38\right)$ and in May $(\mathrm{y}=-2.619 \mathrm{x}$ $\left.+184.45, \mathrm{R}^{2}=0.38, p<0.01, \mathrm{~F}=10.38\right)$, and on water temperature in the same periods $(\mathrm{y}=-2.0182 \mathrm{x}+177.3$, $\left.\mathrm{R}^{2}=0.43, p<0.05, \mathrm{~F}=8.32\right)$ and $(\mathrm{y}=-3.8879 \mathrm{x}+214.1$, $\mathrm{R}^{2}=0.58, p=0.005, \mathrm{~F}=15.37$ ) (Fig. 4). Typically, it is during May when the bulk of larval development occurs, as larvae are usually first detected at the end of April (9 years out of 13) or in the first ten-day period of May (3 years out of 13). The first pupae are most often found at 


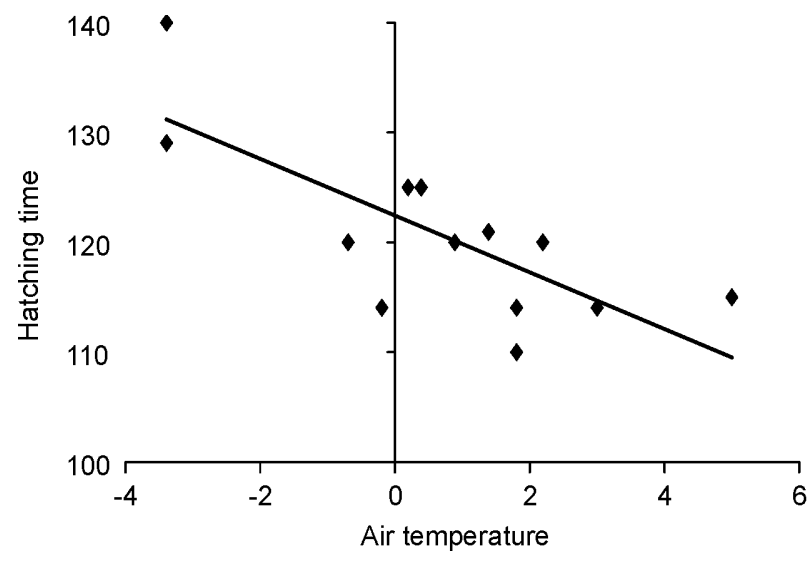

Fig. 3. Dependence of the hatching time (days) of S. maculatum on March air temperature $\left({ }^{\circ} \mathrm{C}\right)$ over the period 1997 to 2009.

the end of May (7 years out of 13) or in the first ten-day period of June (6 years out of 13). The latest appearances of $S$. maculatum pupae (> Upper Quartile) were recorded in 2004, 2005 and 2006 and the earliest (< Lower Quartile) in 2000 and 2002.

The interval between the first appearance of larvae and of pupae each year varied from 21 to 42 days (mean $32 \pm$ 1.6). Black fly development (> Upper Quartile) was longer than the long term average in 1999 and 2004, and shorter (< Lower Quartile) in 2003 and 2005 (Fig. 5). A shorter than average duration of development was also recorded in 2000, 2002 and 2009. The time of pupation is a function of the date of egg hatch and larval developmental rates. Hence, the time of pupation and the duration of development are considered conjointly.

In May 2000 and 2002 water temperature was high (Fig. 6) and the duration of larval development (29 days) was short. In these two years water temperature was high, not only throughout May, but also in the second and third ten-day periods of April, which resulted in the early appearance of larvae. In 2003 the short duration of development (27 days) was associated with water temperature in the first $\left(14.7^{\circ} \mathrm{C}\right)$ and the second $\left(15.7^{\circ} \mathrm{C}\right)$ ten-day periods of May, which was close to the norm, and high water temperatures [up to $19.0^{\circ} \mathrm{C}$ (Fig. 6)] in the third ten-day period of this month.

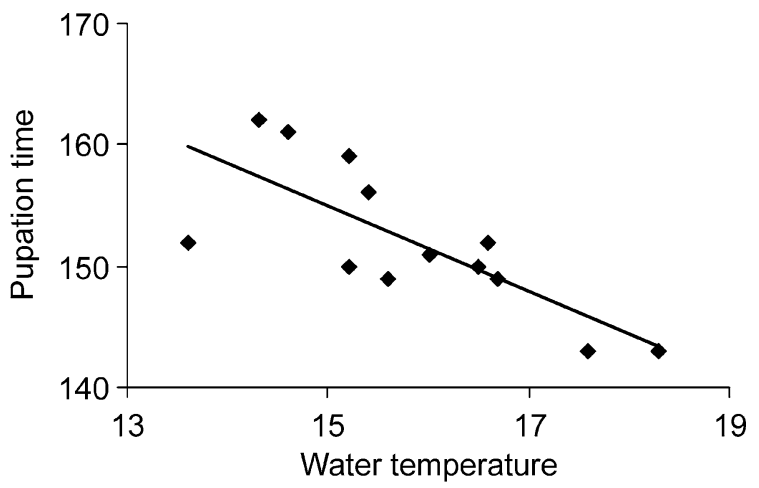

Fig. 4. Dependence of the time of first pupa formation (days) on water temperature $\left({ }^{\circ} \mathrm{C}\right)$ in the river Nemunas (Druskininkai) in May over the period 1997 to 2009.

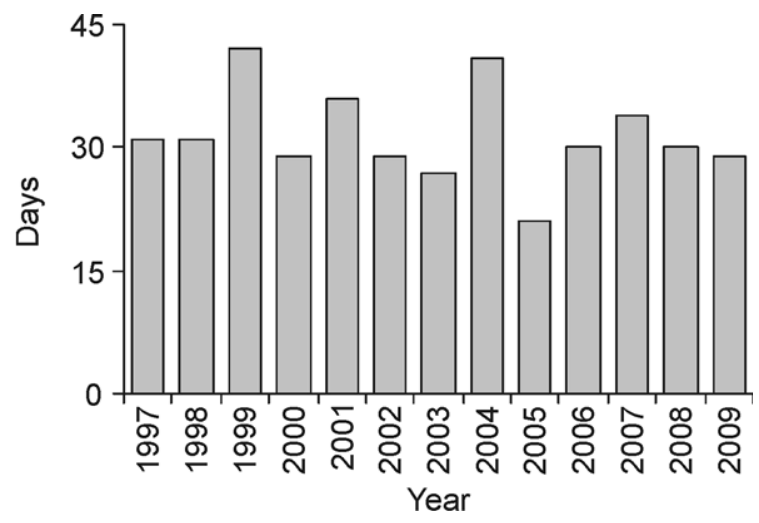

Fig. 5. Duration of development (days) of $S$. maculatum black flies in the years 1997 to 2009 .

In 2005 air temperature in the first and second ten-day periods of May was low and the $S$. maculatum larvae appeared late (at the end of the second ten-day period in May). In the third ten-day period of May the water warmed up (Fig. 6), reaching a temperature of $20-21^{\circ} \mathrm{C}$ in June (www.meteo.lt). These high water temperatures resulted in a short (21 days) period of larval development but nevertheless pupation occurred late because the onset of larval development (Fig. 1) was delayed. The duration of black fly development was exceptionally long in 1999 and 2004. This was associated with low water temperatures in the first $\left(12.4^{\circ} \mathrm{C}, \Delta \mathrm{t}=-1.5^{\circ} \mathrm{C}\right)$ and second $\left(11.0^{\circ} \mathrm{C}, \Delta \mathrm{t}=-4.0^{\circ} \mathrm{C}\right)$ ten-day periods of May 1999 (Fig. 6) and low water temperature (Fig. 6) in the second $\left(13.4^{\circ} \mathrm{C}, \Delta \mathrm{t}=-1.6^{\circ} \mathrm{C}\right)$ and the third $\left(14.5^{\circ} \mathrm{C}, \Delta \mathrm{t}=-2.6^{\circ} \mathrm{C}\right)$ ten-day periods of May, which resulted in a protracted development of black flies (41 days) and late formation of pupae in 2004.

\section{Imagines}

The first $S$. maculatum females attacking people and livestock are usually recorded in the first days of June and are seen flying until the end of June. After the control of black flies in the river Nemunas started in 1998 there was a sharp decrease in the abundance of black fly females in 2000-2001 (Fig. 7). Moreover, in some years (2006, 2008, 2009) only solitary females were recorded. Large numbers (> Upper Quartile) of attacking adults were

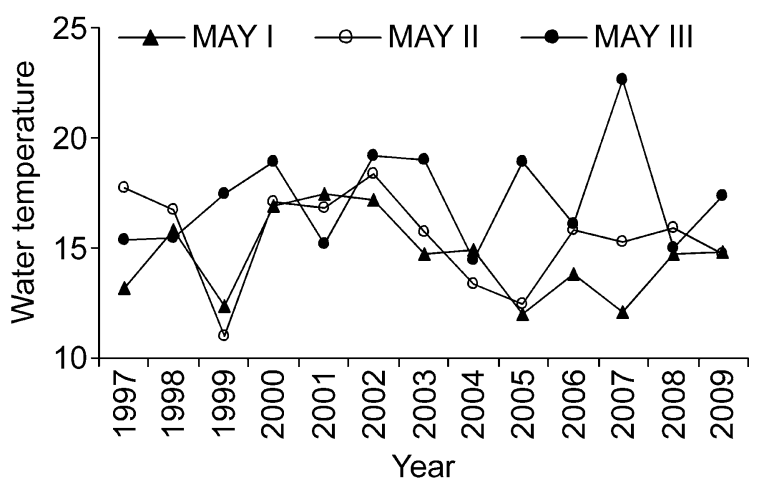

Fig. 6. Temperature $\left({ }^{\circ} \mathrm{C}\right)$ over ten-day periods (I, II, III) in May of the water in the river Nemunas (Druskininkai) in the years 1997 to 2009 . 


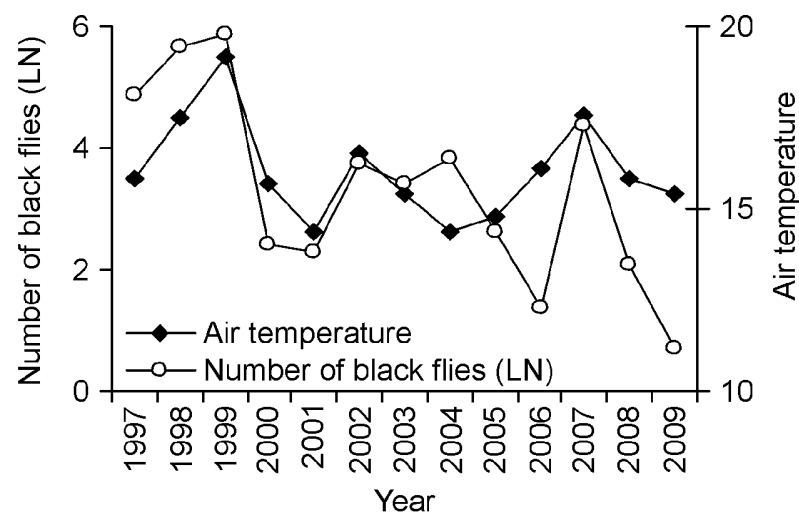

Fig. 7. The number of bloodsucking black flies (LN) and air temperature $\left({ }^{\circ} \mathrm{C}\right)$ recorded at Varena in June from 1997 to 2009.

recorded in 1997, 1998 and 1999, while in 2006, 2008 and 2009 the numbers were much smaller ( $<$ Lower Quartile) (Fig. 7). The highest number of blood-sucking adults was recorded in the first ten-day period in June (8 years out of 13). In 1999, 2001 and 2004 the highest number of attacking females was recorded in the second ten-day period and in 2003 and 2005 in the third ten-day period of June.

The multiple regression analysis of the maximum number of attacking adults, air temperature and precipitation revealed that the maximum number of attacking black flies was affected by air temperature in June $(\mathrm{y}=$ $\left.-66.47 \mathrm{x}+988.02, \mathrm{R}^{2}=0.64, p<0.005, \mathrm{~F}=19.37\right)$ but not influenced by precipitation $(p>0.05)$. The analysis of the thermal regime in separate ten-day periods of June revealed that only the first $\left(\mathrm{y}=-335.58 \mathrm{x}+27.33, \mathrm{R}^{2}=\right.$ $0.4, p<0.005, \mathrm{~F}=7,29)$ and the second $(\mathrm{y}=-472.68 \mathrm{x}+$ $\left.33.71, \mathrm{R}^{2}=0.52, p<0.005, \mathrm{~F}=11.71\right)$ ten-day periods were significantly associated with the abundance of attacking adults.

In 1997 air temperature in June was most often determined by cyclones and precipitation exceeded the norm (75 mm) by $37 \%$ (Fig. 8). The mean air temperature in June was close to the long-term mean, $15.2^{\circ} \mathrm{C}$. The effect of cyclones in the vicinity of the study area favoured convection, i.e. formation of heavy cumulus rain clouds (www.meteo.lt). The periodic precipitation favoured the

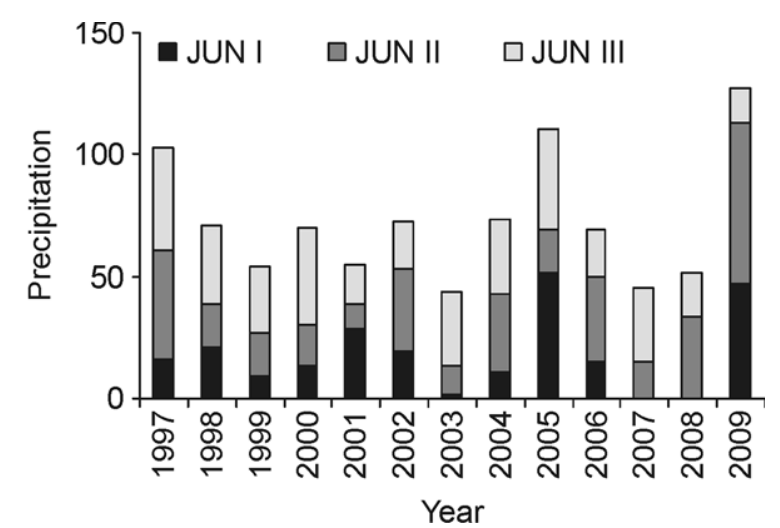

Fig. 8. Precipitation $(\mathrm{mm})$ recorded in ten-day periods of June (I, II, III) at Varèna from 1997 to 2009.

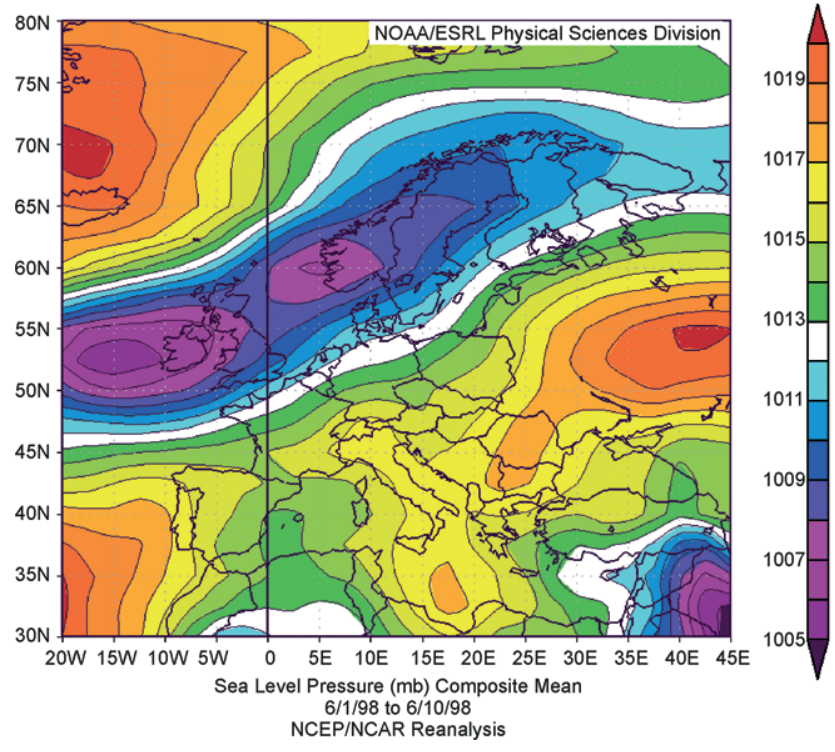

Fig. 9. Composite maps of sea level pressure (SLP) recorded in the first ten-day period in June 1998, when the number of attacking black flies was high.

flight and attack activity of black flies. However, the highest number of attacking black flies was several times lower than that recorded in 1998 and 1999.

In June of 1998 (Fig. 7) air temperature was high, exceeding the norm by $5^{\circ} \mathrm{C}$ in the first-ten day period of the month. Precipitation in June was close to the norm. In the first ten-day period of the month anticyclonic circulation was dominant (Fig. 9) (www.meteo.lt). Hot weather in the first ten-day period of June supposedly favoured the flight activity of black flies.

In 1999, as in 1998, air temperature was high (Fig. 7) and the $54 \mathrm{~mm}$ of precipitation was lower than the norm by $28 \%$ (Fig. 8 ). The weather was most often determined by anticyclones (www.meteo.lt). The abundance of

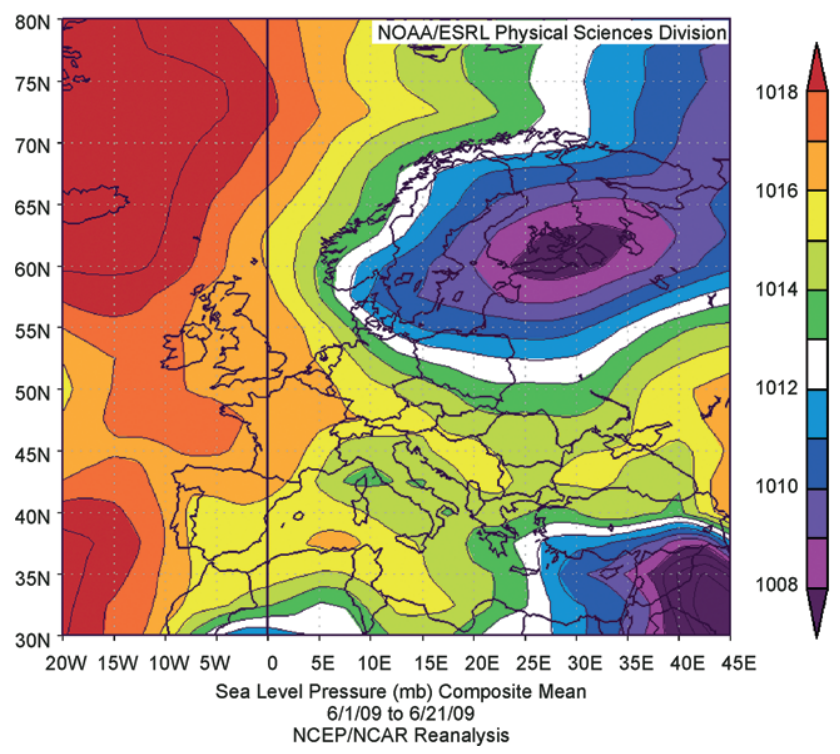

Fig. 10. Composite maps of sea level pressure (SLP) recorded in the first and second ten-day periods in June 2009, when the number of attacking black flies was low. 
attacking blood-sucking black flies in 1999 proved to be the greatest recorded during this study. Sunny, dry, warm, anticyclonic weather ensured ideal conditions for the flight of black flies.

Since 2000 the numbers of attacking black flies were low, due to control by biotechnical means, but varied slightly from year by year, presumably due to meteorological factors.

In 2006 air temperature in June was close to the longterm mean value (Fig. 7). However, in the first ten-day period, the weather, which was most often determined by cyclones, was cloudy and cool (www.meteo.lt). The cool, rainy, cyclonic type of weather was unfavourable for the flight of black flies.

Similarly, June of 2009 was very wet and precipitation exceeded the norm by $69 \%$. Cyclonic circulation that prevailed during the first and the second ten-day periods (Fig. 10) resulted in a low number of flying black flies. In contrast, in June 2007, which was sunny, hot and dry, especially in the first ten-day period during which there was no precipitation (Fig. 8), the intensity of attacks of blood-sucking black flies was comparatively high.

\section{DISCUSSION AND CONCLUSIONS}

Warmer temperatures over the past 30 years have significantly affected seasonal patterns across Europe (Walther et al., 2005). Since 1988 the mean annual and winter air temperatures in Lithuania have been rising, with positive deviations from the long-term 1971-2000 mean temperature prevailing (Bartkevičienè, 2005; Žalakevičius et al., 2006). As there has been an increase in the numbers of outbreaks of black flies in south eastern Lithuania since the 1970s it is hypothesized that this increased black fly activity is associated with changes in the climate.

S. maculatum is widespread throughout the Palaearctic from West Europe to East Siberia and from tundra to Mongolian steppe (Rubtsov, 1956). It is a transpalaearctic species adapted to a continental climate and larvae of $S$. maculatum develop in large warm rivers where the water is rich in organic matter (Yankovsky, 2002). This species is now extinct in Germany and rare in central Europe (Zwick, 1995). Previously, S. maculatum developed abundantly in the Danube, Mogila, Pek and the Juzna Morava Rivers (Živković, 1958) and now it is not detected in South Europe (Ignjatović Ćupina et al., 2006). S. maculatum occurs in Belarus, the Ukraine, Mongolia, Russia, Kazakhstan, China and the USA (Alaska) (Rubtsov, 1956; Trukhan \& Paholkina, 1984; Kaplych \& Skulovetz, 2000; Yankovsky, 2002; Crosskey \& Howard, 2004). Extinction of this species of black fly in central Europe is associated with river pollution (Zwick \& Crosskey, 1980).

Temperature determines when the eggs of Simuliidae hatch each year. For example, eggs of some species hatch in about 4 days at $25^{\circ} \mathrm{C}$, but when stored at temperatures slightly above freezing, at least some eggs remain viable for 2.5 years (Fredeen, 1959). The hatching time of $S$. maculatum in the river Nemunas is usually April-May. This study indicates that the hatching time of $S$. maculatum in Lithuania is associated with winter air tempera- ture, especially that in March. Important for the beginning of $S$. maculatum development is the air temperature in the third ten-day period of April. The relationship between the time of larval eclosion and winter air temperature is due to the fact that mild winters are followed by early warm springs which, in turn, predetermine the earlier beginning of $S$. maculatum development. Factors such as oxygen tension and photoperiod can also affect the rate of developmental of the egg and initiate hatching (Adler et al., 2004).

How quickly larvae complete their development depends on various ecological factors directly or indirectly related to climate (Crosskey, 1990). The most important factor influencing the development of black flies is temperature (Ross \& Merritt, 1978; Merritt et al., 1982). This study indicates that when $S$. maculatum pupated depended on air and water temperatures at the end of April and in May. The thermal regime of water is closely related to air temperature. Changes in water and ground temperatures undoubtedly have a direct effect on the thermal characteristics of rivers (Valiuškevičius, 2007). The development of $S$. maculatum black flies most often occurs in May and the time of pupation was more closely related $\left(\mathrm{R}^{2}\right)$ to water than to air temperature in May.

In Southern Europe adults of S. maculatum emerged approximately one month earlier than in Lithuania (Živković, 1958). The time of pupation depends on the time of egg hatch and rate of development of the larvae. For each species there is a range of water temperatures that are favourable for development. The $S$. verecundum species complex, for example, begins to suffer severe mortality at temperatures below $10^{\circ} \mathrm{C}$ (McCreadie \& Colbo, 1991), whereas the development of Prosimulium approximatum is not curtailed until the temperature drops below $4^{\circ} \mathrm{C}$ (Mansingh \& Steele, 1973; Adler et al., 2004). A rise in water temperature reduces the time it takes black flies to develop. An increase in temperature from 17 to $27^{\circ} \mathrm{C}$, for example, can reduce the duration of development of individuals of the Simulium vittatum species complex (Becker, 1973) by more than half. At a water temperature of $13.2^{\circ} \mathrm{C}$ (1999), the development of $S$. maculatum lasts for 42 days, and at $18.8^{\circ} \mathrm{C}(2005)$, it is half as long (21 days). The above data are similar to those on S. vittatum: the duration of development of this black fly species is reduced to almost half for $5^{\circ} \mathrm{C}$ increase in water temperature.

In conclusion, it is possible to state that the time of hatching of $S$. maculatum depends on the winter and early spring air temperatures. The duration of development (the interval between the appearance of the first $S$. maculatum larvae and formation of the first pupae) depends on water temperature during the development period (May).

The optimal temperature for the adult insects is largely unknown (Adler et al., 2004). This study recorded a positive association between the abundance of attacking black flies and air temperature in June. The anlysis of the relationship between the abundance of attacking black flies and precipitation in separate ten-day periods in June indicated that in 1997-2002 there might be an association but the data for the subsequent years did not confirm this. 
This may be due to either the great reduction in the number of attacking blood-sucking black flies, which has resulted from the use of biotechnical means to control their numbers, distorting the natural flight activity and attack tendencies of black flies, or rainfall is a local phenomenon and its spatial distribution discrete (Bartkevičienè, 2003). The intensity of black fly attacks also depends on other factors such as humidity and wind speed, which were not analyzed (Grace \& Shipp, 1988). Female black flies are generally more prone to bite at low atmospheric pressures and following rapid drops in pressure (Underhill, 1940). The behavioural pattern of the great majority of human-biting black flies in Lithuania [S. reptans (L.), $S$. erytrocephalum (De Geer), S. equinum (L.), S. lineatum $(\mathrm{Mg}$.)] is the same as that cited above: they are active in the evening or in the morning and also before rain. The study of the daily $S$. maculatum attack activity did not reveal any distinct increase in the number of attacking black flies in the evening or in the morning. Black flies of this species are active throughout the day, which is confirmed by data furnished by Živković (1958) from Southern Europe. According to her, the analysis of the 1957-1958 data showed that in the years with cold and rainy springs the adults appeared later. On the other hand, suitable conditions for the massive and early emergence of $S$. maculatum were recorded in the years with dry and warm springs (Živković, 1958). The high intensity of attacks by blood-sucking black flies was associated with little rain and high air temperature. Investigations of the relations between the activity of blood-sucking black flies and some climatic factors will continue in the future.

ACKNOWLEDGEMENTS. Special thanks are extended to L. Monkiene, who translated and edited the text of this manuscript. The authors are thankful for the support of Research Council of Lithuania. We are very grateful to anonymous reviewers for their constructive comments on the manuscript.

\section{REFERENCES}

Adler P.H., Currie D.C. \& Wood D.M. 2004: The Black Flies (Simuliidae) of North America. Cornell University, Ithaca, 941 pp.

BARTKEVIČIENĖ G. 2003: The Impact of North Atlantic Oscillation on the Lithuanian Climate. PhD. Thesis, Vilnius University, Vilnius, $34 \mathrm{pp}$.

BARTKEVIČIENĖ G. 2005: Spatial peculiarities of the NAO impact on air temperature and precipitation field in 1950-2000. Acta Zool. Lit. 15: 39-46.

BeCKer C.D. 1973: Development of Simulium (Psilozia) vittatum Zett. (Diptera: Simuliidae) from larvae to adult at thermal increments from 17.0 to $27.0^{\circ} \mathrm{C}$. Am. Midl. Nat. 89: 246-251.

Bukantis A. 1994: Climate of Lithuania. Vilnius University, Vilnius, $188 \mathrm{pp}$.

Crosskey R.W. 1990: The Natural History of Black Flies. John Wiley, Chichester, $711 \mathrm{pp}$.

Crosskey R.W. \& Howard T.M. 2004: A Revised Taxonomic and Geographical Inventory of World Blackflies (Diptera: Simuliidae). The Natural History Museum, London, 78 pp.

FredeEn F.J.H. 1959: Collection, extraction, sterilization and low-temperature storage of black-fly eggs (Diptera: Simuliidae). Can. Entomol. 91: 450-453.

Grace B. \& ShIPP J.L. 1988: A laboratory technique for examining the flight activity of insects under controlled environmental conditions. Int. J. Biometeorol. 32: 65-69.
Ignjatović Cupina A.I., Petrić D., Zgomba M., Konjević A., Grabovac S. \& MarinKović D. 2006: Estimating the biting risk to humans by the black fly species that are most abundant in the region of Novi Sad (Vojvodina province, Serbia nad Montenegro). Studia Dipterol. (Suppl.) 14: 31-44.

KAPLYCH V.M. \& SKulovetz M.V. 2000: Bloodsucking Blackflies (Diptera, Simuliidae) of Belarus. M. Tanka Belarusian State Pedagogical University, Minsk, 366 pp. [in Russian].

Lemoine N., Schaefer H.-C. \& Böhning-Gaese K. 2007: Species richness of migratory birds is influenced by global climate change. Global Ecol. Biogeogr. 16: 55-64.

Mansingh A. \& Steele R.W. 1973: Studies on insect dormancy. I. Physiology of hibernation in the larvae of the blackfly Prosimulium mysticum Peterson. Can. J. Zool. 51: 611-618.

McCreadie J.W. \& Colbo M.H. 1991: The influence of temperature on the survival, development, growth and chromosome preparation quality of $\mathrm{EFG} / \mathrm{C}, \mathrm{ACD}$, and AA cytotypes of the Simulium venustum - verecundum complex (Diptera: Simuliidae). Can. J. Zool. 69: 1356-1365.

Merritt R.W., Ross D.H. \& Larson G.L. 1982: Influence of stream temperature and seston on the growth and production of overwintering larval black flies (Diptera: Simuliidae). Ecology. 63: 1322-1331.

Pakalniškis S., Bernotiené R., Lutovinovas E., Petrašrūnas A., Podėnas S., Rimšaité J., Saether O.A. \& Spungis V. 2006: Checklist of Lithuanian Diptera. New Rare Lithuan. Insect Spec. (Vilnius) 18: 15-147.

Ross H.D. \& MerRitT R.W. 1978: The larval instars and population dynamics of five species of black flies (Diptera: Simuliidae) and their responses to selected environmental factors. Can. J. Zool. 56: 1633-1642.

RuBTSOv I.A. 1956: Fauna of the USSR. Diptera Insects. Black Flies. Nauka, Moscow-Leningrad, 853 pp. [in Russian].

Trukhan M.N. \& Paholkina N.V. 1984: Bloodsucking Dipterous Insects of Belarus. Nauka i technika, Minsk, 173 pp. [in Russian].

UNDERHILL G.W. 1940: Some factors influencing feeding activity of simuliids in the field. J. Econ. Entomol. 33: 915-917.

VALIUŠKEVIČIUS G. 2007: The impact of global change on inland waters. In Rimkus E. \& Sinkevičius S. (eds): Global Climate Change. Vilnius University, Vilnius, pp. 165-187 [in Lithuanian].

Walther G.R., Berger S. \& Sykes M.T. 2005: An ecological "footprint" of climate change. Proc. R. Soc. Lond. 272: $1427-1432$

YANKOVSKY A.V. 2002: Key for the Identification of Blackflies (Diptera, Simuliidae) of Russia and Adjacent Countries (former USSR). Zoological Institute of the Russian Academy of Sciences, Sankt-Petersburg, 570 pp. [in Russian].

Žalakevičius M., Stanevičíus V. \& BartKevičienè G. 2006: Trends in the composition of breeding bird communities: anthropogenic or climate change-induced process? Acta Zool. Lituan. 16: 165-176.

ŽıvKović V. 1958: O masovnoj pojavi Simulium maculatum u južnom Banatu. [On the outbreak of Simulium maculatum in South Banat.] Acta Veter. (Beograd) 8: 7-14 [in Serbian].

ZwICK H. 1995: Contribution to the European blackfly taxa (Diptera: Simuliidae) named by Enderlein. Aquat. Insects 17: 129-173.

Zwick H. \& Crosskey R.W. 1980: The taxonomy and nomenclature of the blackflies (Diptera: Simuliidae) described by J.W. Meigen. Aquat. Insects 2: 225-247.

ŽYGUTIENĖ M. \& PAKalnIŠKis S. 1997: Blackflies (Diptera, Simuliidae) in Lithuania. Higiena Epidemiol. (Vilnius) 5: 21-24.

ŽygutienĖ M. \& Sprangauskaitè R. 1998: Blood-sucking black flies (Diptera, Simuliidae) in Lithuania. Ekologija 2: 43-46.

Received October 12, 2010; revised and accepted January 13, 2011 